\title{
Distribution and Risk Assessment of Heavy Metals in Soils from a Typical Pb-Zn Mining Area
}

\author{
Shunhong Huang1, Cuiyu Yuan', Qian Li', Yi Yang ${ }^{4}$, Chongjian Tang2,3*, \\ Kun Ouyang ${ }^{1}$, Bing Wang ${ }^{1}$ \\ ${ }^{1}$ Hunan Research Institute for Nonferrous Metals, Changsha 410100, P.R. China \\ ${ }^{2}$ Department of Environmental Engineering, School of Metallurgy and Environment, Central South University, \\ Changsha, 410083, P.R. China \\ ${ }^{3}$ Chinese National Engineering Research Centre for Control and Treatment of Heavy Metal Pollution, \\ Changsha, 410083, P.R. China \\ ${ }^{4}$ College of Resources and Environment, Huazhong Agricultural University, \\ Wuhan, 430070, P.R. China
}

Received: 13 September 2016

Accepted: 11 January 2017

\begin{abstract}
This study focuses on soil heavy metal pollution and the potential ecological risks associated with mining activities. For this work we collected 83 topsoil samples and 11 soil profile samples from a typical abandoned $\mathrm{Pb}-\mathrm{Zn}$ mining area in Hunan Province, China. Concentrations of $\mathrm{Cd}, \mathrm{Pb}, \mathrm{Zn}, \mathrm{Cu}$, and $\mathrm{Ni}$ were measured using Inductively Coupled Plasma Mass Spectrometry (ICP-MS), and As was analyzed by atomic fluorescence spectometry (AFS). The mean concentrations of $\mathrm{As}, \mathrm{Pb}, \mathrm{Cd}$, and $\mathrm{Zn}$ in topsoil were 84.85, $802.58,6.13$, and $689.66 \mathrm{mg} / \mathrm{kg}$, respectively - much higher than Class III of Environmental Quality Standard for soils in China (GB 15618-1995). The most contaminated areas appeared in the vicinity of the mine, discarded smelter, and tailing pond. Heavy metal contents in soils around the tailing pond increased substantially with soil depth, while first increasing and then decreasing with the increased soil depth around the abandoned smelter. The overall potential ecological risks of soil heavy metals in this abandoned mining area were moderate. However, heavy metals in soils around the tailing pond indicated a severe potential ecological risk, which should give rise to widespread concerns.
\end{abstract}

Keywords: heavy metals, mining area, distribution, potential ecological risk

\section{Introduction}

Heavy metals in soil are widespread pollutants of great concern as they are persistent, irreversible, and toxic [1-5]. They can easily accumulate in internal organs

*e-mail: baojia@sut.edu.cn after the consumption of contaminated crops and water, and eventually lead to fatal diseases [6-10]. Mining and smelting operations are important sources of heavy metal contamination in the environment due to activities of mineral excavation, ore transportation, smelting, and refining [11]. Heavy metals present in tailings of former active mines can also be released to surrounding soils, streams, and groundwater mediated by erosion, 
weathering, and leaching over a long duration even after the cessation of mining activity [12-13].

Hunan Province is regarded as the heartland of Chinese non-ferrous mining, with thousands of non-ferrous mining and smelting plants located in this area [14]. Among them, the town of Qingjiang within the city of Chenzhou is one of the typical $\mathrm{Pb}-\mathrm{Zn}$ ore-mining areas that has had a long history of $\mathrm{Pb}-\mathrm{Zn}$ mining activities since the Qing Dynasty. The smelter plant was built here in 1972 and shut down in 1985. Despite the mine and the smelter having been abandoned for a long period, the exploitation and smelting of minerals during such an extended period of time may have led to widespread environmental deterioration in the region. Thus, investigating the heavy metal contents and distribution patterns in soils of this abandoned mining area and properly evaluate the potential risks of these metals are vitally important to better understand the long-term impact of mining activities to the environment and would also be helpful for land management and heavy metal soil remediation.

Numerous investigations have focused on the total heavy metal concentrations in $\mathrm{Pb}-\mathrm{Zn}$ mining areas [15-20]. However, more comprehensive investigations including spatial variation, vertical distribution, and risk assessment of heavy metals in soil from the abandoned $\mathrm{Pb}-\mathrm{Zn}$ mining area were rarely documented. The main goals of this study are: (1) to describe the spatial distribution of heavy metals in topsoil in the abandoned $\mathrm{Pb}-\mathrm{Zn}$ mining area, (2) to analyze the vertical distribution of heavy metals in soil profiles, and (3) to assess the potential ecological risks of the study area using the method of potential ecological risk index.

\section{Materials and Methods}

\section{Sample Area}

Soil samples were taken from the $\mathrm{Pb} / \mathrm{Zn}$ mining area at longitude $113^{\circ} 17^{\prime} 17.76^{\prime \prime} \mathrm{E} \sim 113^{\circ} 17^{\prime} 36.07^{\prime \prime} \mathrm{E}$, latitude $25^{\circ} 45^{\prime} 39.29^{\prime \prime} \mathrm{N} \sim 25^{\circ} 46^{\prime} 1.13^{\prime \prime} \mathrm{N}$, located at Zixing, Chenzhou, Hunan Province, China. The altitude range of the sampling area is $451-335 \mathrm{~m}$.

The sampling area was divided into five parts to characterize the spatial distribution of heavy metals in soil. The locations of sampling areas (A and E) are presented in Fig. 1. Sampling areas A, B, C, D, and E stand for areas around the abandoned smelter, area near the mining waste dump area, orchard, mining area, and area around the tailing pond, respectively.

\section{Sample Collection}

Soil sampling was carried out in September 2012. In total we collected 94 soil samples, including 83 topsoil samples (red plots in Fig. 1), 11 soil profile samples S1-S11
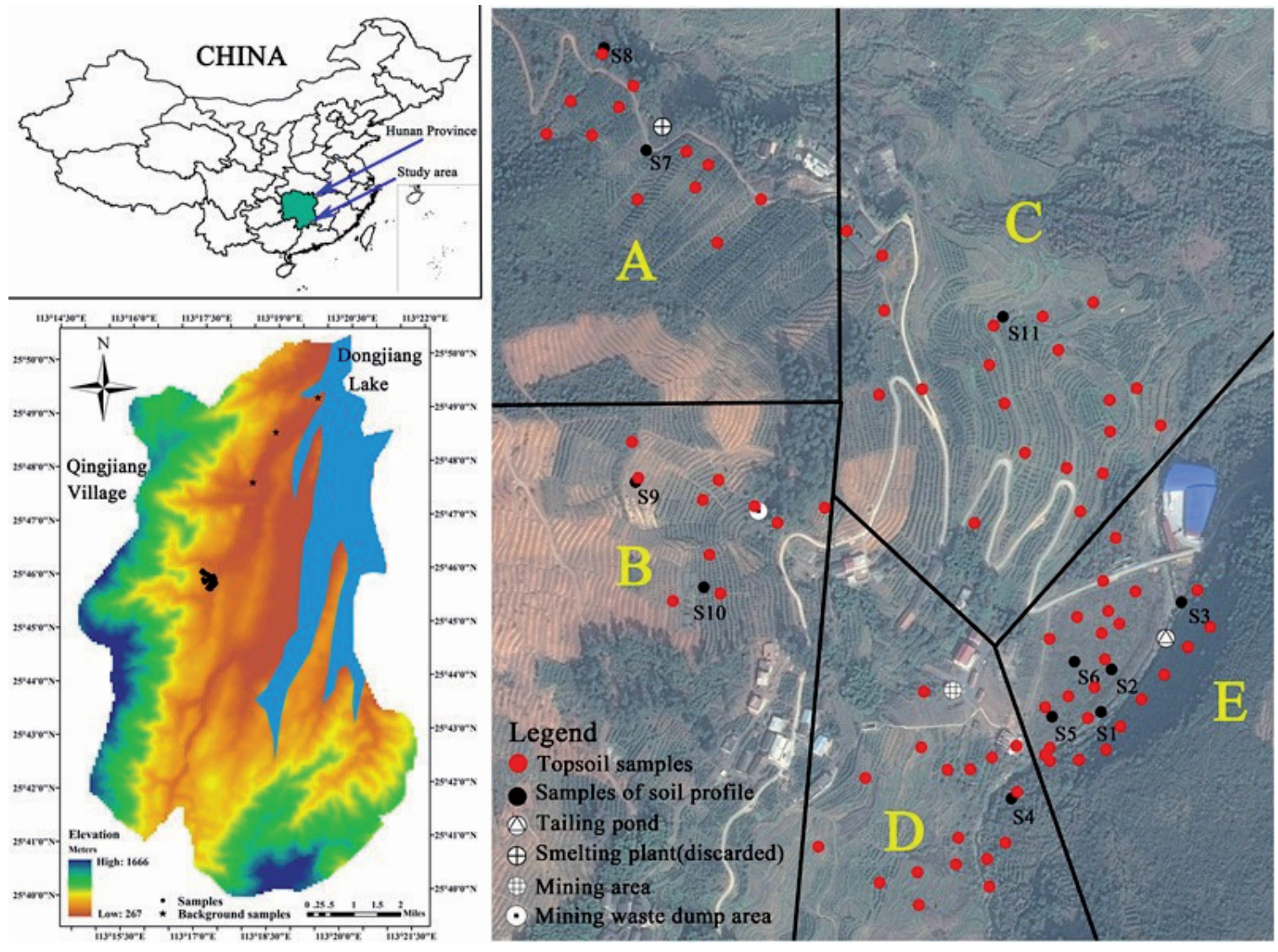

Fig. 1. Sample sites and distribution of sampling points. 
Table 1 . The grading standards of potential ecological risk from heavy metals.

\begin{tabular}{|c|c|c|c|}
\hline$E_{r}^{i}$ & Individual potential ecological risk & $\mathrm{RI}$ & The sum of individual potential ecological risk \\
\hline$E_{r}^{i}<40$ & low potential ecological risk & $\mathrm{RI}<150$ & low ecological risk \\
\hline $40 \leq E_{r}^{i}<80$ & moderate potential ecological risk & $150 \leq \mathrm{RI}<300$ & moderate ecological risk \\
\hline $80 \leq E_{r}^{i}<160$ & considerable potential ecological risk & $300 \leq \mathrm{RI}<600$ & considerable ecological risk \\
\hline $160 \leq E_{r}^{i}<320$ & high potential ecological risk & $\mathrm{RI} \geq 600$ & very high ecological risk \\
\hline$E_{r}^{i} \geq 320$ & very high ecological risk & & \\
\hline
\end{tabular}

(black plots in Fig. 1, including 42 soil samples in different depths), and three background samples. Topsoil samples were collected from a depth of 5-20 cm and profile samples were sectioned at $20 \mathrm{~cm}$ intervals. S1, S2, S3, S5, and S6 were collected from sampling area E. S4 was collected from sampling area D. S7 and S8 were collected from sampling area A. S9 and S10 were collected from sampling area $\mathrm{B}$, and $\mathrm{S} 11$ was collected from sampling area $\mathrm{C}$. The background samples were collected from an area more than 3,000 $\mathrm{m}$ away from the mining area and little affected by anthropogenic activities. Each sample was obtained by mixing four elementary samples collected on the sector. The longitudes and latitudes of the sampling points were recorded in a portable global positioning system (GPS) receiver. Foreign adhered material in collected samples was manually removed. Subsequently, the sample was air-dried at room temperature, disaggregated, and sieved through a 100-mesh sieve for further analysis.

\section{Analytical Methods}

Concentrations of total $\mathrm{Cd}, \mathrm{Pb}, \mathrm{Zn}, \mathrm{Cu}$, and $\mathrm{Ni}$ in soils were measured using inductively coupled plasma mass spectrometry (ICP-MS, JY385, France). As was analyzed by atomic fluorescence spectometry (AFS-230E, Beijing, China).

\section{Assessment Method}

The potential ecological risk index (PERI) method proposed by Swedish scholar Hakanson was employed to evaluate environmental pollution and the ecological damage caused by heavy metals in the mining area soil [21]. The PERI method took into the consideration the toxicology of heavy metals and illustrated the potential ecological risk caused by overall levels of contamination [22]. PERI can be obtained using the following equation:

$$
R I=\sum_{i=1}^{n} E_{r}^{i}=\sum_{i=1}^{n} T_{r}^{i} \times C_{f}^{i}=\sum_{i=1}^{n} T_{r}^{i} \times C_{s}^{i} / C_{n}^{i}
$$

...where PERI is the sum of individual potential ecological risk for all heavy metals, Eri is the potential ecological risk index value of an individual element, is the toxicresponse factor for a given heavy metal, is the present concentrations of heavy metals in surface sediments, and is the reference value of heavy metals. The toxic-response factors for $\mathrm{As}, \mathrm{Pb}, \mathrm{Cd}, \mathrm{Zn}, \mathrm{Cu}$, and $\mathrm{Ni}$ are10, 5, 30, 1,5 , and 5, respectively. The background values of heavy metals were applied as reference values in this work. Table 1 provides the grading standards of potential ecological risk from heavy metals.

\section{Results and Discussion}

\section{Heavy Metal Concentrations}

Heavy metal concentrations in the sampled topsoil are presented in Table 2. In topsoil, the mean concentrations of

Table 2. Heavy metal concentrations in the topsoil samples of mining areas.

\begin{tabular}{|c|c|c|c|c|c|}
\hline & \multicolumn{5}{|c|}{ Heavy metal concentrations in topsoil samples, mg/kg } \\
\hline & Min. & Max. & Mean & BG & Reference value \\
\hline $\mathrm{As}$ & 4.05 & 425.25 & 84.85 & 27.95 & 40.00 \\
\hline $\mathrm{Pb}$ & 54.60 & $6,944.30$ & 802.58 & 89.20 & 500.00 \\
\hline $\mathrm{Cd}$ & 0.01 & 114.73 & 6.13 & 0.60 & 1.00 \\
\hline $\mathrm{Zn}$ & 60.44 & $2,998.05$ & 689.66 & 103.16 & 500.00 \\
\hline $\mathrm{Cu}$ & 6.06 & 115.84 & 25.07 & 17.89 & 400.00 \\
\hline $\mathrm{Ni}$ & 16.35 & 58.64 & 27.63 & 35.67 & 200.00 \\
\hline
\end{tabular}

Reference value: Class III value of the Environmental Quality Standard for Soils in China (GB 15618-1995). 
$\mathrm{Cu}$ and $\mathrm{Ni}$ were below the threshold values of nationwide natural background levels (GB 15618-1995). However, the average concentrations of $\mathrm{As}, \mathrm{Pb}, \mathrm{Cd}$, and $\mathrm{Zn}$ exceeded their corresponding limits of Class III Environmental Quality Standards for soils in China (GB 15618-1995), with the mean concentrations of $\mathrm{As}, \mathrm{Pb}, \mathrm{Cd}$, and $\mathrm{Zn}$ being $84.85,802.58,6.13$, and 689.66, respectively (Table 2). Moreover, $\mathrm{As}, \mathrm{Pb}, \mathrm{Cd}$, and $\mathrm{Zn}$ were 3.04, 8.99, 10.22, and 6.69 times their background values, respectively. These results reflect the long-term mining and smelting activities a)

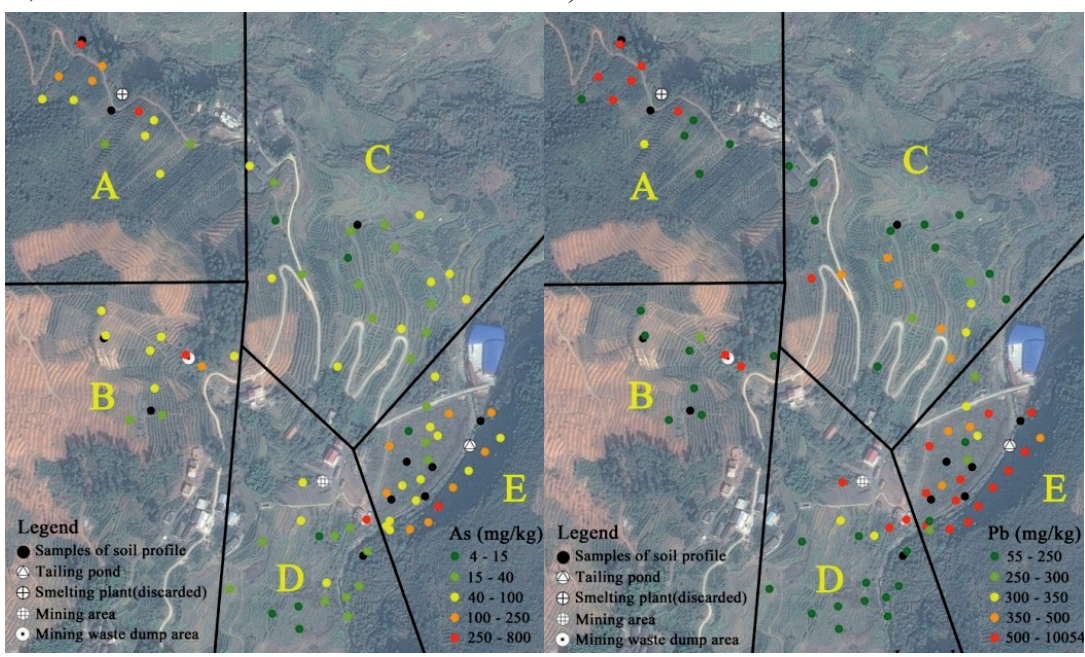

c)

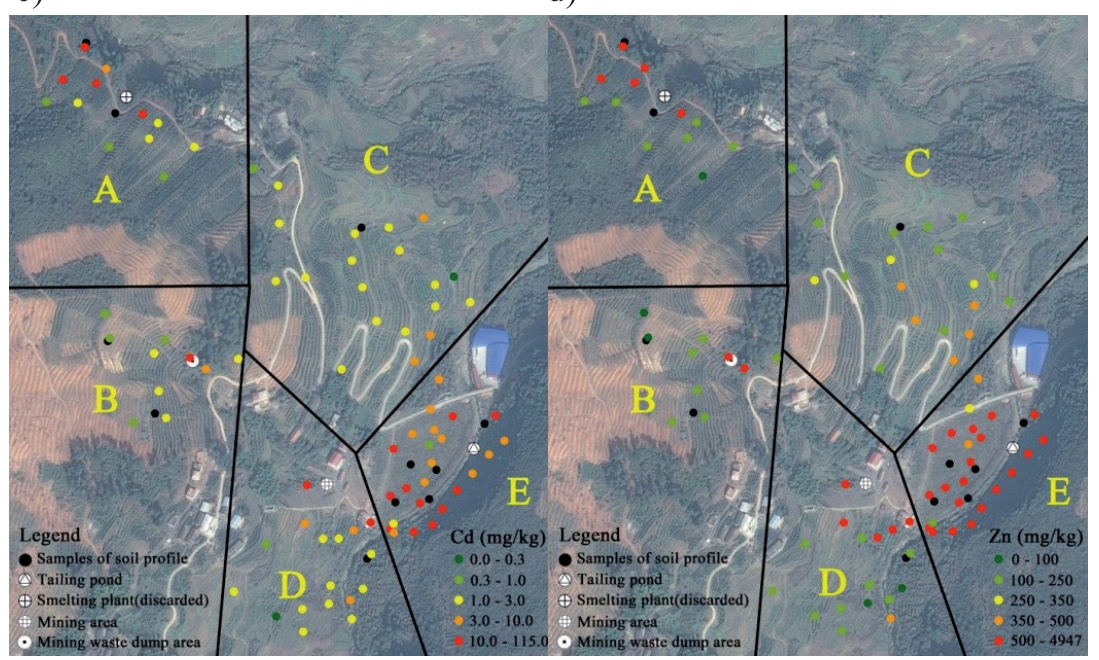

e)

f)

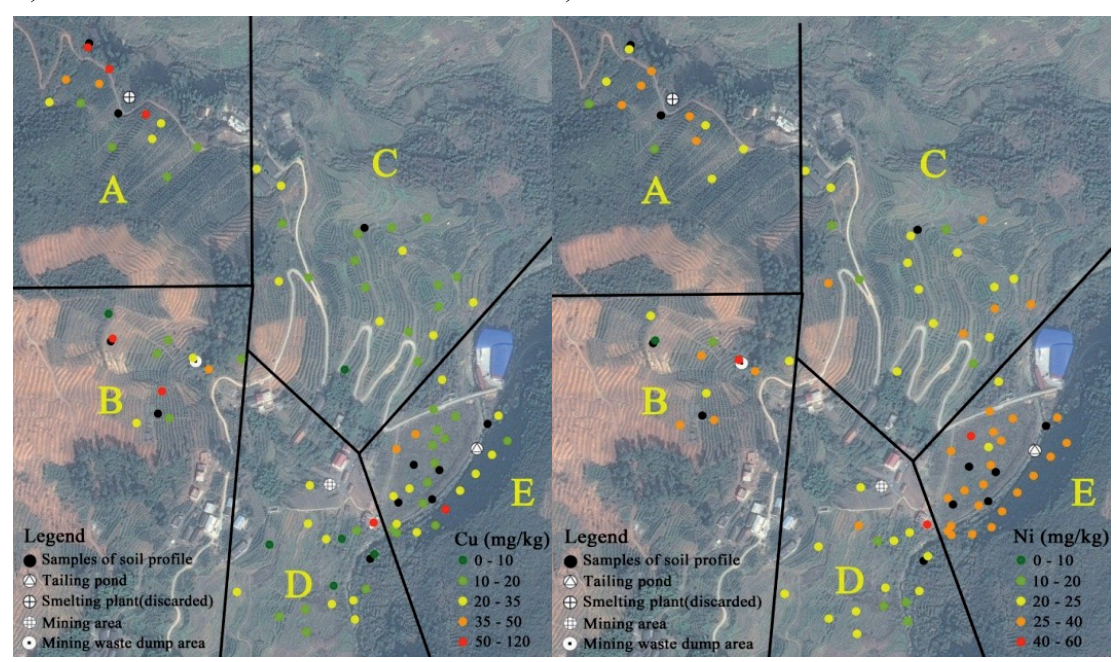

Fig. 2. Spatial distribution of heavy metals in topsoil samples: a) $\mathrm{As}, \mathrm{b}) \mathrm{Pb}, \mathrm{c}$ ) $\mathrm{Cd}$, d) $\mathrm{Zn}$, e) $\mathrm{Cu}$, and f) $\mathrm{Ni}$. 

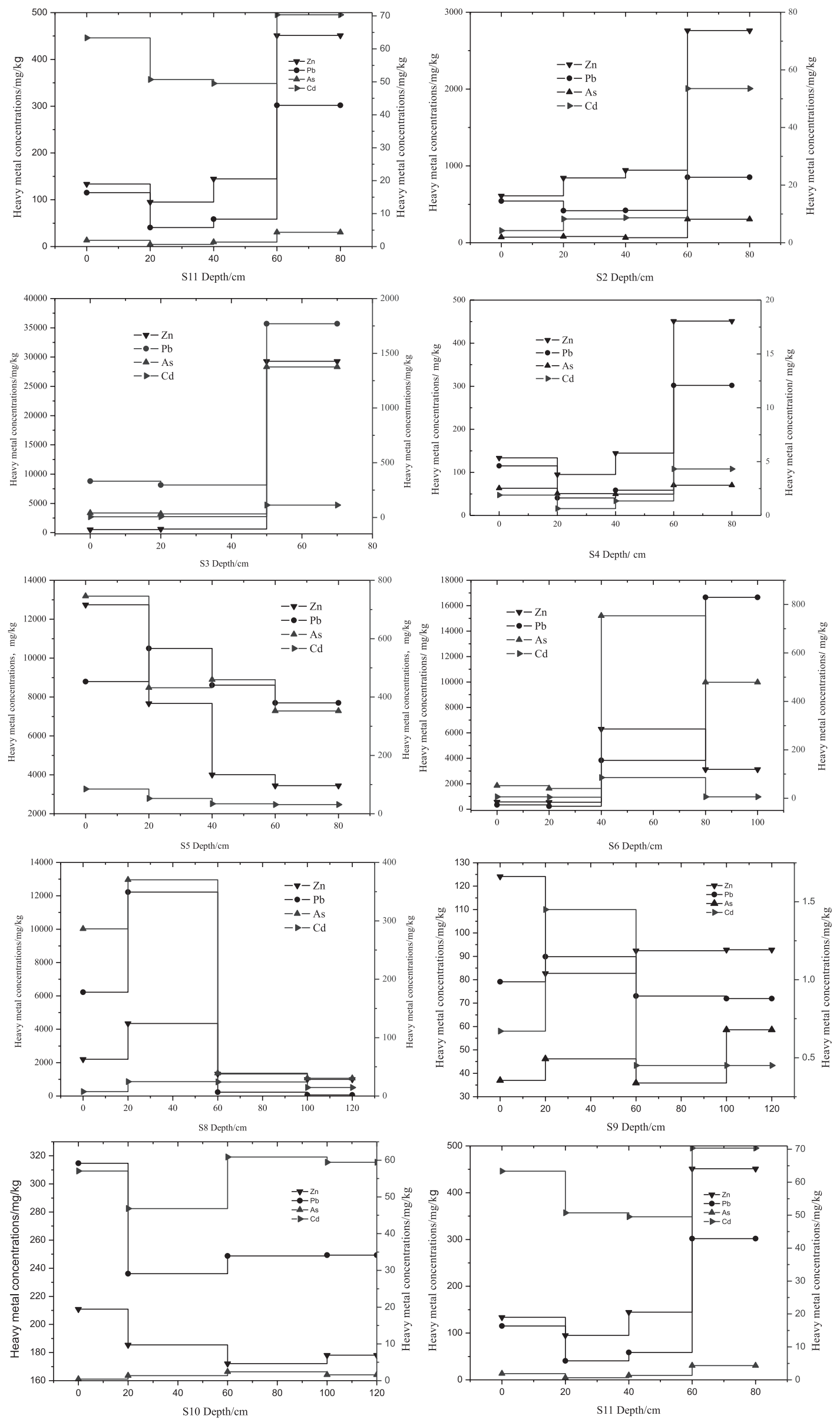

Fig. 3. Vertical distribution of heavy metals in soil profiles. 
that have led to significant accumulations of $\mathrm{As}, \mathrm{Pb}, \mathrm{Cd}$, and $\mathrm{Zn}$ in topsoil.

\section{Spatial Distribution of Heavy Metals in Topsoil}

A geographic information system (ArcGIS 10.1) was used to investigate the spatial distributions of the heavy metals since it allows unit divisions to be evaluated rapidly and gives sufficiently accurate results [23]. The spatial distribution of heavy metals in topsoil is shown in Fig. 2. The variations of $\mathrm{As}, \mathrm{Pb}, \mathrm{Zn}$, and $\mathrm{Cd}$ demonstrated a very similar pattern, with the most heavily contaminated areas appearing in the mining waste dump area and in the vicinity of the mine, discarded smelting plant, and tailing pond. High concentrations of $\mathrm{Pb}$ and $\mathrm{Zn}$ reflect the main components of the minerals extracted from the mine sites, such as galena $(\mathrm{PbS})$ and sphalerite $(\mathrm{ZnS})$, while $\mathrm{Cd}$ and As were by-products in the smelting/refining of $\mathrm{Pb}-\mathrm{Zn}$ ores and also by-products of acid mine drainage [24]. According to Mélida Gutiérrez et al. [25], Cd is closely associated with $\mathrm{Zn}$, and its chemical similarity with $\mathrm{Zn}$ allows it to replace $\mathrm{Zn}$ in $\mathrm{Zn}$ minerals, thus $\mathrm{Cd}$ demonstrates a very similar pattern with that of $\mathrm{Zn}$. The hotspot of $\mathrm{Pb}$ and $\mathrm{Zn}$ appeared in sampling area $A$ (discarded smelting plant), which reached $10.01 \mathrm{~g} / \mathrm{kg}$ for $\mathrm{Pb}$ and $4.95 \mathrm{~g} / \mathrm{kg}$ for $\mathrm{Zn}$, while the hotspot $\mathrm{Cd}$ appeared in sampling area B (near the mining waste dump area), with its content as high as $42.53 \mathrm{mg} / \mathrm{kg}$. The hotspots of $\mathrm{As}, \mathrm{Pb}, \mathrm{Cd}$, and $\mathrm{Zn}$ in the vicinity of a discarded smelting plant may have resulted from the airborne emissions of aerosols and volatile particulates of the chimneys, whereas the hotspot of high $\mathrm{As}, \mathrm{Pb}, \mathrm{Cd}$, and $\mathrm{Zn}$ levels near the tailing pond were due to the leaching and chemical weathering of tailings. Moreover, high levels of As $(>250 \mathrm{mg} / \mathrm{kg})$ can be found in soils of former smelter locations and near the tailing pond, which is in good agreement with the results reported by Wei et al. [26] that the high level of As in soils caused by dispersal from chimneys of the smelters could be found at a distance of about $6-8 \mathrm{~km}$. The spatial distribution of $\mathrm{Cu}$ and Ni didn't show significant regularity. This means that the $\mathrm{Pb}-\mathrm{Zn}$ mining and smelting activity had little effect on the spatial distribution of $\mathrm{Cu}$ and $\mathrm{Ni}$.

\section{Vertical Distribution of Heavy Metals in Soil Profiles}

Typical soil profile samples were collected from each sampling area to investigate the variation of the heavy metal concentrations with increased soil depths. Fig. 3 shows the vertical distribution of heavy metals in these typical soil profiles.

As can be seen from Fig. 3, high concentrations of $\mathrm{Pb}$, $\mathrm{Zn}$, and Cd were detected in S1, S2, S3, S5, S6, S7, and $\mathrm{S} 8$. The mean contents of $\mathrm{As}, \mathrm{Pb}, \mathrm{Zn}$, and $\mathrm{Cd}$ in the five soil profiles collected from sampling area E (S1, S2, S3, S5, and S6) were as high as 343.09, 909.74, 2,948.41, and $25.56 \mathrm{mg} / \mathrm{kg}$, respectively, which were $8.58,1.82,5.90$, and 25.56 times their corresponding limits of Class III of the Environmental Quality Standard for soils in China (GB 15618-1995). This result reflects the significant accumulations of $\mathrm{As}, \mathrm{Pb}, \mathrm{Cd}$, and $\mathrm{Zn}$ in soil profiles of sampling area E. As for S9, S10, and S11, only Cd contents were presented in excessive levels. These results are in good agreement with the results reported in literature that $\mathrm{Cd}$ is more mobile than $\mathrm{Zn}$ and $\mathrm{Pb}$ [27-28].

The vertical distribution profiles in each sampling area showed different patterns. Heavy metals contents in $\mathrm{S} 1, \mathrm{~S} 2, \mathrm{~S} 3$, and S6 collected from sampling area E were generally found to increase substantially with increasing soil depth. This depended on its structure composition. Since there were tailings underneath sampling area E, the content of heavy metals spurt with the soil depth increased to the tailings layer. The heavy metal content of S5 decreased with the increased soil depth. The wastewater of ore dressing plant inflow to the region resulted in the migration of the heavy metals in wastewater from surface to underground. Heavy metals in S7 and S8 showed a tendency to increase at first and then decreased with the increasing soil depth with a significant accumulation in $40-60 \mathrm{~cm}$ depth. In addition to sample site S4, the heavy metal content decreased with increasing soil depth, the heavy metal distribution in S9, S10, and S11 didn't show significant regularity.

\section{Potential Ecological Risk Assessment of Heavy Metals in Topsoil}

Potential ecological risks related to heavy metals in soils were calculated based on Eq. (1). The potential ecological risk index value varied from 6.16 to $3,561.31$,

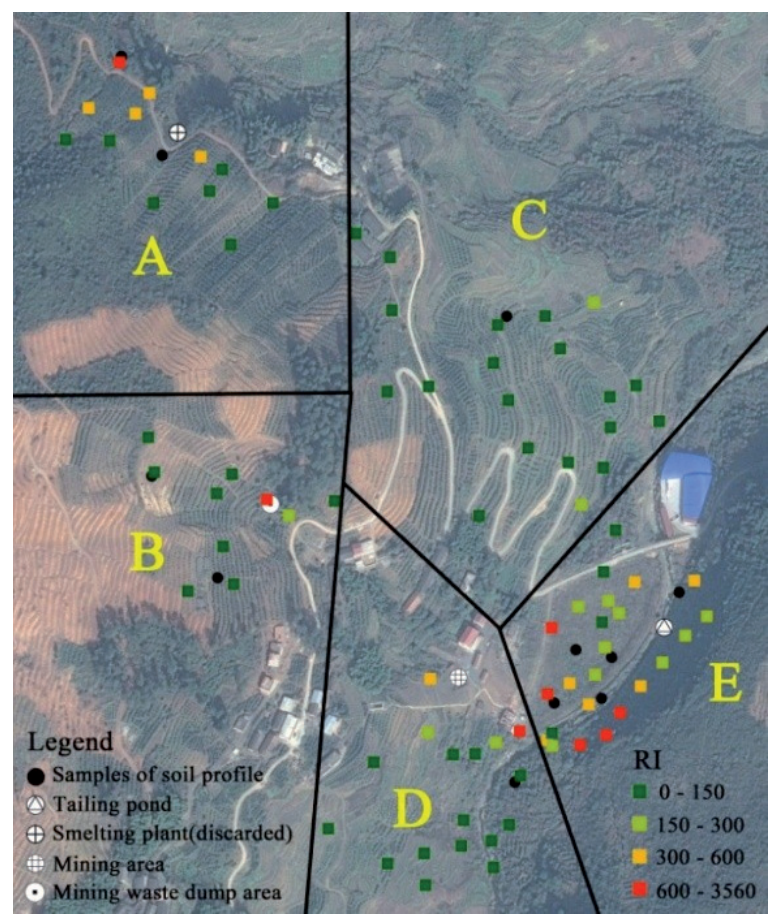

Fig. 4. The spatial distribution of risk index (RI) of heavy metals in the sampling area. 
with the mean potential ecological risks of heavy metals in the sampling area being 248.38, which indicated heavy metals in more than $39.76 \%$ of soil samples possessing moderate and higher ecological risks. The average potential ecological risk index of the study area was greater than 150 and less than 300, indicating that total potential ecological risk was moderate.

The average RI values of the single sampling area decreased in the following order: $\mathrm{E}>\mathrm{A}>\mathrm{B}>\mathrm{D}>\mathrm{C}$. In addition to sampling areas $\mathrm{C}$ and $\mathrm{D}$, the integrated potential ecological risk index of the single sampling area was greater than 150 , indicating that sampling areas E, A, and $\mathrm{B}$ were at moderate risk or above. Among them, the average RI value of sampling area E was 522.64 - greater than 300 .

The spatial distribution of risk index (RI) of heavy metals in every sampling area is shown in Fig. 4, in which we can see that the potential ecological risk of heavy metals in sampling area $\mathrm{C}$ (the orchard) was generally low. However, eight samples with a potential ecological risk index higher than 600 were detected in other sampling areas, indicating that this sampling site posed a very high ecological risk. It should be also pointed out that $26 \%$ of soil samples were with considerable ecological risk and about $20 \%$ of soil samples were with very high ecological risk in sampling area E. Furthermore, two hotpots with RI values as high as 1,342.55 and 3,561.31 were in sampling area $\mathrm{E}$. The results indicate that heavy metals in sampling area $\mathrm{E}$ pose severe potential ecological risks to the local ecological system and that human health and should be given serious concern.

\section{Conclusions}

The detected levels of As, $\mathrm{Cd}, \mathrm{Zn}$, and $\mathrm{Pb}$ in the longterm abandoned mining areas were much higher than the national thresholds, indicating the impending need to fully investigate and assess the suitability of the land for further agricultural use. The variations in $\mathrm{Pb}, \mathrm{Zn}$, and $\mathrm{Cd}$ demonstrated a very similar pattern, with the most heavily contaminated areas appearing in the vicinity of the mine, smelter, and tailing pond. The vertical distribution profiles in each sampling area show different patterns. Heavy metals contents in the vicinity of the tailing pond were generally found to increase substantially with increased soil depth. Heavy metal concentrations in the area near the former smelter location first increased and then decreased with increasing soil depth. The potential ecological risk results show that the total potential ecological risk was moderate. While sampling area E poses severe potential ecological risk to the local ecological system, this area should give rise to widespread concern.

\section{Acknowledgements}

This study was supported by the Opening Foundation of the Chinese National Engineering Research Center for Control and Treatment of Heavy metal Pollution, Changsha, 410083, China (No. 2015CNERC-CTHMP-16) and the Key Program of Science and Technology of Hunan Province, China (2014FJ1011).

\section{References}

1. WANG Q.R., CUI Y.S., LIU X.M., DONG Y.T., PETER C. Soil Contamination and Plant Uptake of Heavy Metals at Polluted Sites in China. J. Environ. Sci. Heal. A, 38 (5), 823, 2003.

2. OSMA E., SERIN M., LEBLEBICI Z., AKSOY A. Assessment of Heavy Metal Accumulations $(\mathrm{Cd}, \mathrm{Cr}, \mathrm{Cu}, \mathrm{Ni}$, $\mathrm{Pb}$, and $\mathrm{Zn}$ ) in Vegetables and Soils. Pol. J. Environ. Stud., 22 (5), 1449, 2013

3. QU C.S., SUN K., WANG S.R., HUANG L., BI J. Monte Carlo simulation-based health risk assessment of heavy metal soil pollution: a case study in the Qixia mining area, China. Hum. Ecol. Risk Assess., 18 (4), 733, 2012.

4. OBIORA S.C., CHUKWU A., TOTEU S.F., DAVIES T.C. Assessment of heavy metal contamination in soils around lead $(\mathrm{Pb})$-zinc $(\mathrm{Zn})$ mining areas in Enyigba, southeastern Nigeria. J. Geol. Soc. India, 87 (4), 453, 2016.

5. HU W.Y., HUANG B., HE Y., KALKHAJEH Y.K. Assessment of potential health risk of heavy metals in soils from a rapidly developing region of China. Hum. Ecol. Risk Assess., 22 (1), 211, 2016.

6. ATAFAR Z., MESDAGHINIA A., NOURI J., HOMAEE M., YUNESIAN M., AHMADIMOGHADDAM M., MAHVIS A.H. Effect of fertilizer application on soil heavy metal concentration. Environ. Monit. Assess., 160 (1-4), 83, 2010.

7. DOUAY F., PELFRENE A., PLANQUE J., FOURRIER H., RICHARD A., GIRONDELOT B. Assessment of potential health risk for inhabitants living near a former lead smelter. Part 1: metal concentrations in soils, agricultural crops, and homegrown vegetables. Environ. Monit. Assess., 185 (5), 3665,2013

8. ZHANG X.W., YANG L.S., Li Y.H., LI H.R., WANG W.Y., Ye B.X. Impacts of lead/zinc mining and smelting on the environment and human health in China. Environ. Monit. Assess., 184 (4), 2261, 2012.

9. YAN W.B., MAHMOOD Q., PENG D.L., FU W.J., CHEN T., WANG Y., LI S., CHEN J.R., LIU D. The spatial distribution pattern of heavy metals and risk assessment of moso bamboo forest soil around lead-zinc mine in Southeastern China. Soil Till. Res., 153, 120, 2015.

10. RAHBAR M.H., SAMMS-VAUGHAN M., DICKERSON A.S., LOVELAND K.A., ARDJOMAND-HESSABI M., BRESSLER J., SHAKESPEARE-PELLINGTON S., GROVE M.L., BOERWINKLE E. Factors associated with blood lead concentrations of children in Jamaica. J. Environ. Sci. Heal. A, 50 (6), 529, 2015

11. LIN W.J., XIAO T.F., ZHOU W.C., NING Z.P. Pb, Zn, and Cd Distribution and Migration at a Historical Zinc Smelting Site. Pol. J. Environ. Stud., 24 (2), 575, 2015.

12. LEE M., PAIK I.S., KIM I., KANG H., LEE S. Remediation of heavy metal contaminated groundwater originated from abandoned mine using lime and calcium carbonate. J. Hazard Mater., 144 (1-2), 208, 2008.

13. RODRIGUEZ L., RUIZ E., ALONSO-AZCARATE J., RINCONB J. Heavy metal distribution and chemical speciation in tailings and soils around a $\mathrm{Pb}-\mathrm{Zn}$ mine in Spain. J. Environ. Manage. 90 (2), 1106, 2009. 
14. WANG Z.X., CHEN J.Q., CHAI L.Y., YANG Z.H., HUANG S.H., ZHENG Y. Environmental impact and site-specific human health risks of chromium in the vicinity of a ferroalloy manufactory, China. J. Hazard Mater., 190 (1-3), 980, 2011.

15. FACCHINELLI A., SACCHI E., MALLEN L. Multivariate statistical and GIS-based approach to identify heavy metal sources in soils. Environ. Pollut., 114 (3), 313, 2001.

16. RODRIGUEZ J.A., NANOS N., GRAU J.M., GIL L., LOPEZ-ARIAS M. Multiscale analysis of heavy metal contents in Spanish agricultural topsoils. Chemosphere, 70 (6), 1085, 2008.

17. KAPUSTA P, SZAREK-LUKAZEWSKA G, STEFANOWICZ A.M. Direct and indirect effects of metal contamination on soil biota in a $\mathrm{Zn}-\mathrm{Pb}$ post-mining and smelting area (S Poland). Environ. Pollut., 159 (6), 1516, 2011.

18. MONTERROSO C., RODRIGUEZ F., CHAVES R., DIEZ J., BECERRA-CASTRO C., KIDD P.S., MACIAS F. Heavy metal distribution in mine-soils and plants growing in a $\mathrm{Pb} / \mathrm{Zn}$-mining area in NW Spain. Appl. Geochem., 44 (3), 3, 2014.

19. BRIKI M., JI H.B., LI C., DING H.J., GAO Y. Characterization, distribution, and risk assessment of heavy metals in agricultural soil and products around mining and smelting areas of Hezhang, China. Environ. Monit. Assess., 187 (12), 1, 2015.

20. ALIU M., ŠAJN R., STAFILOV T. Spatial distribution of lead in soils of $\mathrm{Pb}-\mathrm{Zn}$ mining and smelting area of the Mitrovica Region, Republic of Kosovos. J. Environ. Sci. Heal. A, 51 (7), 588, 2016.
21. HANKANSON L. An ecological risk index for aquatic pollution control: a sedimentological approach. Water Reasearch., 14 (8), 975, 1980.

22. QIU H.Y. Studies on the Potential Ecological Risk and Homology Correlation of Heavy Metal in the Surface Soil. J. Agr. Sci., 2 (2), 194, 2010.

23. ACOSTA J.A., FAZ A., MARTINEZ S., ZORNOZA R., CARMONA D.M., KABAS S. Multivariate statistical and GIS-based approach to evaluate heavy metals behaviour in mine sites for future reclamation. J. Geochem. Explor., 109 (1), 8, 2011.

24. OBIORA S.C., CHUKWU A., DAVIES T.C. Heavy metals and health risk assessment of arable soils and food crops around $\mathrm{Pb}-\mathrm{Zn}$ mining localities in Enyigba, southeastern Nigeria. J. Afr. Earth. Sci., 116, 182, 2016.

25. GUTIERREZ M., MICKUS K. CAMACHO L.M. Abandoned $\mathrm{Pb}-\mathrm{Zn}$ mining wastes and their mobility as proxy to toxicity: A review. Sci. Total Environ., 565, 392, 2016.

26. WEI C.Y., WANG C., YANG L.S. Characterizing spatial and sources of heavy metals in the soils from miningsmelting activities in Shuikoushan, Hunan Province, China. J. Environ. Sci., 21 (9), 1230, 2009.

27. ZHAN H.Y., JIANG Y.F., YUAN J.M., HU X.F., NARTEY O.D., WANG B.L. Trace metal pollution in soil and wild plants from lead-zinc smelting areas in Huixian county, northwest China. J. Geochem. Explor., 147, 182, 2014.

28. KEROLLI-MUSTAFA M., FAJKOVIC H., RONCEVIC S., ĆERKOVIC L. Assessment of metal risks from different depths of jarosite tailing waste of Trepça zinc industry, Kosovo, basedon BCR procedure. J. Geochem. Explor., 148, 161, 2015. 